\title{
HISTORICAL EVOLUTION OF THE LAW
}

\section{P. Tărchilă}

\author{
Assoc. Prof. Petru Tărchilă \\ Faculty of Humanities and Social Sciences \\ University Aurel Vlaicu of Arad \\ *Correspondence: University Aurel Vlaicu of Arad \\ E-mail: danielacret@yahoo.com,drept@uvvg.ro
}

\begin{abstract}
The entire community acted according to these rules because their disobedience had an influence on the survival of the entire community, as they had a powerful mystical and religious character. Sanction measures evolved along with the evolution of communities and they were applied to individuals who disobeyed and broke these rules. Thus, the first forms of human community used the death penalty (blood revenge ${ }^{1}$ ) as means of punishment for serious violation of the rules of coexistence. Later on, death penalty was replaced by the individual's expulsion from the community and as communities evolved, material redemption was used instead of expulsion. The first judicial norms (the germs of law) developed among these social cohabitation, organization and behaviour rules. Judicial norms differed from other rules due to their compulsory character and by appeal to the coercive force of the community when they were broken by certain individuals. The change of social, customized norms into judicial norms and the emergence of law as independent entity take place along with the occurrence of state and public power rooted in the Greek-Roman Antiquity. It has been set that law is a social phenomenon incidental to human society; thus, Romans have expressed this statement through the phrase: "ubi societas, ibi jus", namely law occurs along with the society. Law, like society is not a static, immutable entity issued once and for all; they are under constant development and social-historical evolution. As social phenomenon, social law experiences a constant historical evolution, bearing the mark of historical periods and cultural, spiritual and religious features of nations.
\end{abstract}

Keywords: custom, social norm, juridical norm, regulation.

\section{Introduction}

Man is a social and sociable creature whose place in within a community. Thus emerge the needs for organization, order, discipline, all leading to the occurrence of behaviour rules, to sets of norms that would harmonize the individuals' interests to the interests of the community as part of the collective interest. Along with the evolution of human society and its organization in families, races and tribes, we witness the emergence of first behaviour rules embedded in skills, habits, customs, etc. The entire community acted according to these rules because their disobedience had an influence on the survival of the entire community, as they had a powerful mystical and religious character.

\footnotetext{
${ }^{11}$ see I. Craiovan, Teoria generala a dreptului, Ed. Sibila, Craiova, 2009, pp. 11-15.
} 


\section{The law classification}

Behaviour rules have developed and evolved along with the evolution of human communities, changing into social norms of cohabitation, organization and behaviour. The evolution of the community brought about the evolution of penalties applied to individuals who disobeyed or broke those rules. Thus, the first forms of human community used the death penalty (blood revenge ${ }^{2}$ ) as means of punishment for serious violation of the rules of coexistence. Later on, death penalty was replaced by the individual's expulsion from the community and as communities evolved, material redemption was used instead of expulsion.

The first judicial norms (the germs of law) developed among these social cohabitation, organization and behaviour rules. Judicial norms differed from other rules due to their compulsory character and by appeal to the coercive force of the community when they were broken by certain individuals. The change of social, customized norms into judicial norms and the emergence of law as independent entity take place along with the occurrence of state and public power rooted in the Greek - Roman Antiquity. It has been set that law is a social phenomenon incidental to human society; thus, Romans have expressed this statement through the phrase: "ubi societas, ubi jus", namely law occurs along with the society. Law, like society is not a static, immutable entity issued once and for all; they are under constant development and social-historical evolution. As social phenomenon, social law experiences a constant historical evolution, bearing the mark of historical periods and cultural, spiritual and religious features of nations. Over time there have been several theories on the classification and ordering of the law. Some of them are listed below:

- a theory centred on the basic characteristics of form and content of the law classifies it into law systems or law families. For instance, the Roman-Germanic law system founded on the Roman Law and blended with German, Spanish, French, etc. doctrine; the common-law system founded on the English Law, etc.

- another theory founded on the chronological and historical criterion of the emergence of judicial norms groups the law in types of law. Thus, the Marxist Theory mentions four types of law: slave-owning, feudal, burgher and proletarian (socialist). The following classification of types of law can be taken into consideration:

- incipient law (early law) typical for the primitive society;

- Medieval law typical for the Middle Ages;

- modern law typical for the beginning of Capitalism;

- contemporary law which tends to share common features due to international public and private law but can still be grouped into:

- the law of democratic societies;

- socialist law;

- the law of developing countries;

- community law, etc.

\subsection{The factors which influence the law and its judicial norms}

The analysis of factors which influence the judicial norms of the law involves the identification of causes and metrical forces that generate it and determine a judicial regulation or another. Various concepts and philosophical theories have sought to identify

\footnotetext{
${ }^{2}$ see I. Craiovan, Teoria generala a dreptului, Ed. Sibila, Craiova, 2009, pp. 11-15.
} 
these factors, referring to politics, morality, ideology, economy, etc. Thus, there are the following factors:

develops

a) geographical, demographic, biological factors where human existence

These factors influence judicial norms to a certain extent.

See the differences between judicial norms of overpopulated countries and those of underpopulated ones, between states placed in arid and dry areas and those placed in wet, green areas.

b) historical, ethnical, national factors

These factors take into account historical conditions and the ethnical-national peculiarities of population. See the differences between states with homogenous ethnical structure and those with multi-ethnical population or consisting of several minorities.

c) social-economic factors

These factors are determined by the level of economic development, the nature of property forms, the structure of social layers, professional categories of the society, etc. See the effort made by Romania to create the legal framework for economic reformation after the shift to a market economy. We can notice that there is interdependence and mutual influence between economy and law and the role of law in regulating social relations increases along with the historical development of a society.

d) political factors

These factors play a determining role in the development of judicial norms in a certain society. Changes in the political regime in former socialist states after the fall of totalitarian regimes had an overwhelming consequence on all branches of law, especially on constitutional law.

e) cultural - ideological factors

These factors sum up the artistic, cultural, spiritual creation, ideology and religion which will occur in judicial norms of all branches of law in a society at a certain point. (called the reference point).

f) international factors

These factors refer to the international situation, the relationship with the neighbouring countries, the state's relationship to international institutions, etc., factors with a powerful influence on the judicial norms (international public and private law, diplomatic law, etc.).

The sum of these factors influences to a larger or smaller extent the elaboration and evolution of judicial norms of a society at a certain reference point. But specialists in judicial norms consider that the fundament of law in a society is the human factor in his complexity and dynamics of his features and relationships. Thus, the needs, interests, aspirations and actions in various situations (citizen, owner, public servant) have to be taken into account. This factor along with other factors will bring about the elaboration, transformation and replacement of judicial norms with newer ones and thus determine the evolution of law in a society.

\section{The functions and finalities of law}

\subsection{Law as independent institution}

The core of law can be expressed in terms of will and interests of a society at a certain reference point. In law, the role of will has a double significance. It is the general 
will of social classes or even the society`s, governed by general interests and made official by the state as a guarantor for law obedience. On the other hand, it is the individual's, the citizen's will visible in the process of law application.

Law can be presented in various ways. It is the product of social deeds and the man`s will, a historical phenomenon and normative order, an aggregate of will acts and authority, of freedom and constraint. ${ }^{3}$

The problem with defining law is not of mere theoretical importance but it has also practical implications. As an author noticed, the legal advisor has to seek solutions and not aspects related to the definition of law and its sources of knowledge. But how the legal advisor uses the technique, his horizon and the quality of approached solutions depend on the answer to these issues. Kant, in his work "Metaphysical Elements of Justice" drew attention upon the fact that solution in law, according to the text of positive law, issues the question: what is justice, what is the law itself?

Those who study law have to accept the pluralism of answers, that several definitions of law are available, their variety and relativity but also their tendency to present the core of law. Their perennial character is marked by a series of objective and subjective factors such as: historical time, philosophy of the period, various judicial movements and law schools as well as the author`s personality.

In this perspective, law as it has been seen throughout the years is not mere historical illustration but a necessary endeavour for the understanding of its complex significances.

In judicial writings, authors have tried to group the definitions of law and therefore in 1985, J.F. Bergel's work "Theorie general du droit" classifies them as follows:

1. Definitions of formal - normative type, which present law as an aggregate of behaviour rules which regulate social reports in a more or less organized society; their obedience is ensured by public constraint, if necessary".

2. Definitions of substantial type - they aim the reason of being, the origin, justification and conclusiveness of law.

Definitions given by different authors are undoubtedly very significant for the judicial beliefs of the author, thus the famous philosopher Immanuel Kant defines law as "the sum of conditions when an individual's free will can coexist with everyone's free will according to an universal law of freedom."

A remarkable contribution to the development of general theory of law was made by Mircea Djuvara (1886-1945). He considered that "law is a product of human reason no matter how rudimentary it was in primitive societies and the manner law functions is the result of this product".

Professor Djuvara classifies law in: rational law and positive law. Rational law involves abstract judgements and results in appreciations on what is just or unjust, legal or illegal.

Positive law is represented by the law practiced in society and is contained by bills, customs, jurisprudence and other sources. The Romanian recent judicial doctrine through the voice of professor I. Ceterchi defined law as "the system of behaviour norms, written or acknowledged by the state, which guide human behaviour according to the social values of a society, setting rights and judicial obligations whose obedience is enforced by public power, if necessary (represented by the state and its institutions).

\footnotetext{
${ }^{3}$ See Sofia Popescu, Conceptii contemporane despre drept, Ed. Academiei, Bucharest, 2010, pp. 74-75.
} 


\section{P. Tărchilă}

\subsection{The finalities of law}

Professor Nicolae Popa defines law as "an aggregate of state-guaranteed rules whose purpose is to organize and discipline human behaviour in the main relationships of a society, in a freedom-governed climate that protects human rights and social justice". After analysing various definitions of law issued throughout the years, we can list its main characteristics. Thus, law has a:

a. social character because it places the human being in relation and interactivity with another human being.

b. anti-entropic character, namely its ability to oppose to disaggregation, disorder and social conflicts. Law has always been a regulating and ordination factor in the society because it confers certainty, peace, safety and protection to the people who obey it.

c. normative character because it represents what is and what should be in a society in the form of specific, general and impersonal rules.

d. imperative character, characterized by the provision of judicial norm; the provision must be obeyed by all people and its disobedience will be punished by the coercive force of the state (through its institutions).

e. value character which is generated, structured and directed in relationship with other values of the society, according to historical time it has been issued.

f. educational character which involves its ability to develop a collective but also compelling relationship to those who break the law

g. architect of social life characterized by its ability to accustom to good discipline and educate the society's behaviour so as to respect and defend social values.

h. historical character which is represented by the influence of spatial-temporal coordinates upon judicial norms and law in general. Thus, law is subjected to historical evolution, judicial norms are specific configurations of one country or another; it is influenced by the historical period it was issued in because of the influence of natural, social, economic, cultural, political and international factors.

The functions and finalities of law are complex, dynamic and contradicting. They sum up several ways, manners and moral, cultural and normative mechanisms through which society imposes the individual (all members of a society) a series of constraint and interdictions. Thus, the individual has to obey norms and basic values promoted and defended by the society.

This process takes place under social control which identifies the main mechanisms and levers by means of which society ensures the social cohesion of its members, the stability and functionality of its institutions.

The term "social control" was introduced into the vocabulary of judicial sociology by the American school of "sociological jurisprudence". It stipulates that law has an important role and it is considered the most perfectible and complex manner of social control. The sociological theory of law considers it highly dependent on the global social system of a society. The functions of law have been defined as fundamental directions or orientations of the judicial mechanism. The whole system (norms, institutions of law) along with institutions authorized by the society ${ }^{4}$ are involved in achieving these directions.

The Italian professor V. Ferrari ${ }^{5}$ considers that law as three may functions:

\footnotetext{
${ }^{4}$ see N Popa, Teoria generala a dreptului, Ed. Actomi, Bucharest, 1996, p. 80.
} 
1) social regulation

2) conflict solving

3) legitimation of power

Professor N. Popa believes that law fulfils the following four main functions:

1) institutionalization and judicial formalization of social-political organization

2) preservation, defence and guarantee for the fundamental values of a society

3) rule over society

4) normative function

Law as part of the social system is perfective. It is subjected to constant changes and its positive effects on the social life and economic, administrative and political activities of a society are visible.

There are also cases when the relationship between the law and the social system is subjected to severe disturbing phenomena. They can generate real legal dysfunctions ${ }^{6}$ represented by the law`s impossibility to express itself efficiently or by distorting the law. The situations can be the following:

1. when law misses from social relations or from fields where it should be used. The phenomenon was analysed by the French Professor J. Carbonnier and called "nonlaw" phenomenon. It can have the following characteristics: self-limitation of law in time and space, namely judicial activity is not enforced on certain days, holidays or at night. For example: trials are not held on legal holidays, houses are not searched during the night, etc.

2. lack of validity and efficiency. These causes can be determined by internal or external causes, in situations when laws do not take into consideration the technical legal conditions or certain judicial principles. Here count also laws that face public resistance or have lost their object, thus becoming obsolete.

3. the existence of judicial norms that affect seriously the social values and even the notion of social justice (unjust law).

4. repressive (oppressive) law when the harmful effects of unjust judicial norms are experienced by certain social classes or categories, thus violating the human fundamental rights and freedom ${ }^{7}$.

We need to have a closer look on the finalities of the law in order to be able to establish its role, importance and place in the society. The understanding and analysis of law finalities means presenting its reason of being, goal and ideals as well as its development tendencies.

\section{Conclusions}

With the evolution of human society and its organization in families, races and tribes, we witness the emergence of first behaviour rules embedded in skills, habits, customs, etc. The entire community acted according to these rules because their disobedience had an influence on the survival of the entire community, as they had a powerful mystical and religious character. Sanction measures evolved along with the evolution of communities and they were applied to individuals who disobeyed and broke these rules. Thus, the first forms of human community used the death penalty (blood revenge $^{8}$ ) as means of punishment for serious violation of the rules of coexistence. Later

\footnotetext{
${ }^{5}$ see V. Ferrari, Funzioni del Diritto, bari, 1987, p. 25.

${ }^{6}$ see I. Craiovan, Teoria generala a dreptului, Ed. Sibila, Craiova, 2009.
} 


\section{P. Tărchilă}

on, death penalty was replaced by the individual's expulsion from the community and as communities evolved, material redemption was used instead of expulsion. The first judicial norms (the germs of law) developed among these social cohabitation, organization and behaviour rules. Judicial norms differed from other rules due to their compulsory character and by appeal to the coercive force of the community when they were broken by certain individuals. The change of social, customized norms into judicial norms and the emergence of law as independent entity take place along with the occurrence of state and public power rooted in the Greek - Roman Antiquity. It has been set that law is a social phenomenon incidental to human society; thus, Romans have expressed this statement through the phrase: "ubi societas, ibi jus", namely law occurs along with the society. Law, like society is not a static, immutable entity issued once and for all; they are under constant development and social-historical evolution. As social phenomenon, social law experiences a constant historical evolution, bearing the mark of historical periods and cultural, spiritual and religious features of nations.

\section{Bibliography}

1. Banciu, D., Control social si sanctiuni sociale, Ed. Hyperion, Bucuresti, 2012, p. 10

2. Craiovan, I., Teoria generala a dreptului, Ed. Sibila, Craiova, 2009.

3. Djuvara, M., Teoria generala a dreptului, Bucuresti, 1930.

4. Popa, N., Teoria generala a dreptului, Ed. Actomi, Bucuresti, 1996, p. 80.

5. Popescu, S., Conceptii contemporane despre drept, Ed. Academiei, Bucuresti, 2010, p. 74-75.

\footnotetext{
${ }^{7}$ See D. Banciu, Control social si sanctiuni sociale, Ed. Hyperion, Bucharest, 2012, p. 10
} 